\title{
PSIKOTERAPI PENDEKATAN SUFISTIK DALAM MENANGANI MASALAH AGAMA DAN MORAL REMAJA
}

\author{
Oleh: Dasril *
}

\begin{abstract}
:
This article discusses conceptually the approach of suffistic psychotherapy in handling religious and moral problems of Moslem teenagers. Among those problems are: drug abuse, drunks, students fights, free sex, and lack of religious practices. The above mentioned approach is believed to be able to solve the problems by encouraging the teenagers to recite the Holy Qoran, to perform late night prayer (qiyamul lail), to do fasting (compulsory and optional as well), to pray and to have self evaluation (mubasabah) more.
\end{abstract}

Kata kunci : psikoterapi sufistik, menangani masalah agama, dan moral remaja

\section{PENDAHULUAN}

$\mathrm{S}$ ekarang ini di dunia masalah-masalah yang tumbuh pada manusia lebih komplek. Demikian juga di Indonesia sebagai negara berkembang dan berpenduduk muslim terbesar di dunia. Sebagian masyarakat Indonesia masih hidup dalam kemiskinan dan derasnya arus golablisasi maka hal ini akan berpengaruh pada kehidupan anakanak dan remaja.

Berbagai media baik televisi, radio dan media cetak setiap hari tiada hentinya memberitakan banyak masalah sosial dan keagamaan yang menimpa anakanak remaja dan orang dewasa. Di antara masalah tersebut seperti pergaulan bebas, narkotika, minuman keras, kekerasan geng remaja (seperti nero,) serta lemahnya pengamalan agama. Berbagai upaya telah dilakukan oleh pemerintah baik dengan membuat undang-undang, menghukum secara fisik bahkan sampai adanya hukumman matipun ternyata itu belum membuat jera para pelaku.
Berdasarkan hal di atas maka menurut hemat penulis untuk mengatasi hal tersebut diperlukan terapi-terapi pendekatan keagamaan. Terapi di sini sama dengan pembersihan jiwa, yaitu pembersihan hati dan akal manusia dari kekotoran dosa, dari keinginan keinginan untuk berbuat dosa dan penyelewengan, serta menimbulkan rasa takut pada diri manusia untuk melakukan kesalahan dan sebgai proses penting dalam kembali ke fitrah manusia.

Hati merupakan organ penting dalam tubuh manusia, dimana jika hati itu baik maka baiklah tubuh yang lainnya dan sebaliknya jika hati tersebut rusak maka rusaklah tubuh yang lainnya. Sebagaimana hadist yang diriwayatkan alBukhari dan Muslim yang artinya : Sesungguhnya dalam jasad manusia ada segumpal daging, apabila ia baik, maka baiklah seluruh anggotanya, dan jika ia rusak maka rusaklah seluruh anggota tubuh itu, itulah dia hati. Artinya jika hati manusia itu telah rusak maka yang akan keluar dari dirinya adalah per-

* Penulis adalah Asisten Ahli dalam Mata Kuliah Bimbingan Konseling pada STAIN Batusangkar 
buatan-perbuatan jahat dan sulit baginya untuk dapat berbuat baik.

Berdasarkan hal di atas maka di sini penulis tertarik membahas bagaimana pendekatan psikoterapi sufistik dalam membantu menangani persoalan agama dan moral remaja yang bersumber dari rusaknya hati, khususnya remaja muslim dewasa ini yang sudah membuat berbagai kalangan kesulitan dalam mencari solusinya.

\section{PENGERTIAN PSIKOTERAPI}

Psikoterapi merupakan pengobatan alam pikiran, atau lebih tepatnya, pengobatan dan perawatan gangguan psikis melalui metode psikologis (Rita L Arkinson; tt : 491). Sedangkan menurut James P Chaplin (1999:407) secara khusus psikoterapi adalah Penerapan teknik khusus pada penyembuhan penyakit mental atau pada kesulitan-kesulitan penyesuaian diri setiap hari. Secara luas, psikoterapi mencakup penyembuhan lewat keyakinan agama melalui pembicaraan informal atau diskusi personal dengan guru atau teman.

Menurut Dahlan (2005:12) penyembuhan atau terapi mengandung makna pengembalian fungsi kalbu sebagai nurani, kata hati dan sanubari. Sebelum penyembuhan uji dulu apakah suara suara dan kata hati itu masih berfungsi atau tidak. Suara hati yang berfungsi akan membisikkan nada indah, penuh kasih, ingin menolong, penuh rasa maaf dan tanggung jawab yang bersifat universal, oleh siapapun dan dimanapun. Sebaliknya apabila suara hati tidak berfungsi, maka suasana ceria , kasih sayang tidak akan muncul dalam diri kita.

Psikoterapi yang penulis maksud di sini adalah upaya pengobatan/ penyembuhan hati remaja yang menimbulkan munculnya masalah agama dan moral remaja melalui berbagai terapi dengan pendekatan nilai-nilai sufistik
Islam, seperti dengan memperbanyak tilawah al-Quran, banyak berzikir, melakukan puasa, shalat malam dan senantiasa melakukan instropeksi diri (muhasabah/kontemplasi)

\section{MACAM-MACAM PSIKOTERAPI}

Menurut Muhammad Mahmud Mahmud (1984:402) psikoterapi ada 2 Jenis Psikoterapi, yaitu

\section{Psikoterapi Bersifat Duniawi}

Yaitu berupa pendekatan dan teknik pengobatan psikis setelah memahami psikopatologi dalam kehidupan nyata model ini lebih banyak digunakan untuk penyembuhan dan pengobatan psikopatologi yang biasa menimpa pada sistem kehidupan duniawi manusia, seperti: Neurastenia, histeria, psyicastenia, schizoprenia, manic devresif, kelainan seks, paranoian psikosomatis dsb.

\section{Psikoterapi Bersifat Ukhrawi}

Berupa bimbingan mengenai nilainilai moral spiritual agama yang merupakan hasil petunjuk (hidayah) dan anugrah (wabbah) dari Allah swt. Terapi ini lebih ditekankan kepada bagaimana seseorang yang mengalami masalah dapat melakukan hal-hal yang dapat mendekatkan diri kepada yang maha kuasa, yang mana terapi ini juga disebut dengan psikoterapi hati.

\section{MASALAH AGAMA DAN AKHLAK REMAJA}

\section{Pengertian Masalah}

Menurut Siti Rahayu Haditomo (1972:57) masalah adalah ketidak mampuan anak memenuhi kebutuhannya akan menimbulkan ketegangan-ketegangan dalam jiwanya sehingga timbul mekanisme tingkah laku atau pertahanan 
diri yang kebanyakan berupa male adjustment yang merupakan cara penyelesaian atau pelarian dari kenyataan. WS Winkel (1985:12) memberikan depenisi bahwa masalah adalah sesuatu yang menghambat, merintangi, mempersulit dalam usaha mencapai tujuan.

Prayitno (1999) memberikan beberapa ciri suatu masalah yaitu:

(a) suatu hal yang tidak disukai keberadaannya.

(b) suatu yang dapat menimbulkan, mendatangkan kesulitan dan kerugian baik untuk sekarang maupun akan datang.

(c) bagi orang yang telah menyadari adanya masalah maka ia ingin segera menghilangkannya.

Dari berbagai pendapat di atas diambil kesimpulan bahwa masalah agama dan moral adalah segala sesuatu yang menghambat, merintangi dan mengganggu pikiran serta perasaan individu sehingga terjadi pelanggaran nilai agama dan moral dalam diri individu dalam memenuhi kebutuhan hidupnya.

\section{Jenis-jenis Masalah}

Setiap orang memiliki masalah dalam hidupnya, hanya saja masalah yang dirasakan berbeda antara satu individu dengan individu lainnya. Meskipun masalah itu berbeda, namun bisa dikelompokkkan dalam bidang-bidang tertentu. Berkaitan dengan perbedaan di atas, Winkel (1985:12) mengelompokkan masalah kepada masalah keluarga, masalah sekolah belajar, masalah pengisian waktu senggang dan masalah dengan diri sendiri.

Sementara itu Prayitno dkk (1997:2) mengelompokkan masalah secara umum kepada sepuluh bidang masalah, yaitu ;

a. Masalah bidang Jasmani dan Kesehatan (JDK)

b. Masalah diri pribadi (DPI)

c. Masalah hubungan sosial d. Masalah ekonomi dan keuangan

e. Masalah karir dan pekerjaan

f. Masalah pendidikan dan pengajaran

g. Masalah hubungan mudi

h. Masalah keadaan hubungan keluarga

i. Masalah agama nilai dan moral

j. Masalah waktu senggang.

Dari dua pendapat di atas dapat dilihat salah satu aspek yang dikemukakan oleh prayitno dkk adalah adanya masalah berkaitan dengan agama dan nilai moral remaja. Di mana pada saat ini masalah agama nilai dan moral merupakan masalah terbesar yang dihadapi bangsa kita. Masalah ini terjadi di sekolah mulai dari SLTP sampai dengan perguruan tinggi dan juga di masyarakat, baik di perkotaan maupun di pedesasaan yang terpencil sekalipun.

\section{Masalah Agama dan Akhlak/moral Remaja}

Masalah agama dan moral remaja hari ini betul-betul amat mencemaskan dan sampai pada tahap yang memprihatinkan. Dimana setiap hari media masa, baik televisi, koran, radio senantiasa memaparkan kepada kita secara vulgar bagaimana terjadinya berbagai persoalan agama dan moral remaja. Di antara masalah tersebut seperti terjadinya seks bebas beberapa remaja SMA di bogor maret 2007, perkelahian antar geng, penganiayaan mahasiswa STPDN oleh kakak senior sampai meninggal, dimana mereka menyiksa para yuniornya sebagai ajang balas dendam tanpa rasa takut akan dosa dan kasihan pada yuniornya, banyaknya mahasiswa yang tertangkap sebagai wanita penjaja seks di samping berpropesi sebagai mahasiswa perguruan tinggi. Serta beberapa hari ini juga kita dikejutkan dengan peristiwa penyiksaan oleh mahasiswa STIP terhadap yuniornya yang ujung-ujungnya juga meninggal dunia.

Di samping persoalan moral di atas juga banyaknya ditemukan remaja (sis- 
wa dan mahasiswa) yang tidak begitu peduli lagi dengan nilai-nilai agama. Banyaknya mahasiswa yang secara berpakaian tidak menutup aurat, tidak mau melakasanakan ibadah, jarang membaca alquran, meninggalkan solat karena kuliah, olah raga dan sebagainya sudah menjadi kebiasaan. Mesjid sebagai sarana ibadah dan peningkatan iman sudah sepi, tempat-tempat hiburan jadi rame dan lebih menarik.

\section{FAKTOR YANG MEMPENGARUHI AKHLAK}

Menurut Prof Dr. Mizan Abdillah (2008:2 belum ada dalam referensi) Secara umum ada lima faktor yang mempengaruhi kebaikan /keburukan Akhlak manusia yaitu faktor hati, faktor genetik, faktor lingkungan, faktor makanan dan faktor pengetahuan agama.

\section{Faktor Hati}

Hati dalam terminology tasawwuf disebut dengan " Nafs Al Natiqa " atau Nafs Rasional".hati disebut dengan nafs rasional karena seseorang akan sampai pada tingkat perkembangan hati jika ia telah mencapai tingkat kesempurnaan Nafs sehingga ia memiliki Nafs yang tenang. Javad Nurbakhsy (2000: 135 belum ada dalam referensi) menjelaskan bahwa hati merupakan tempat di antara wilayah ruh dan Nafs. Ruh adalah sumber dari semua kebaikan; sedangkan nafs adalah sumber dari semua kejahatan Antara ruh dan nafs dalam diri individu merupakan dua kutub yang saling tarik menarik. Pemenang antara ruh dan nafs dalam diri individu, itulah yang akan mengendalikan hati.

Ketika hati manusia dikuasai nafs, maka saat itulah individu itu disebut dengan individu yang tidak memiliki hati atau hati yang mereka miliki telah mati. Akan tetapi jika hati mampu melepaskan belenggu-belenggu nafs yang ada pada dirinya, maka secara otomatis individu itu akan berada di bawah pengaruh ruh, maka pada saat itulah manusia itu dengan seseorang yang telah memiliki hati; karena makna sebenarnya hati adalah bersih dari segala kekotoran nafs.

Menurut al-Gazali hati merupakan tempat keimanan, kekufuran, ketaatan, kemaksiatan serta puncak segala kebaikan dan kejahatan, malah ia dianggap sebagai raja yang menguasai dan mengarahkan segala aktifitas yang dilakukan oleh seluruh anggota badan manusia

\section{Faktor Genetik}

Genetik merupakan faktor biologikal yang mempunyai peranan dalam mempengaruhi akhlak manusia. Bisa dimisalkan seperti biji benih yang tidak baik di tanam, akhirnya menghasilkan buah yang rusak Oleh sebab itu dalam Islam Nabi Muhammad saw menyuruh pemuda /pemudi mencari pasangan hidup dari golongan yang baik dan berakhlak mulia serta memberi keutamaan kepada aspek tersebut dibandingkan dengan kecantikan dan kekayaan. Hadist riwayat bukhari dan muslim artinya: wanita dinikahi karena 4 hal yaitu: harta, kecantikan, keturunan dan agama, hendaklah kamu memilih karena agamanya (berakhlak mulia) niscaya kamu beruntung.

\section{Faktor Lingkungan}

Suasana sekeliling tempat manusia tinggal dan hidup bersama dengan orang lain bisa memberikan kesan kepada psikologi, pikiran, emosi dan tingkah laku mereka. Jika individu tinggal di lingkungan yang rusak akhlaknya maka elemen elemen negatif akhirnya mempengaruhi tingkah laku mereka. Karena itulah sebetulnya orang tua (ibu dan bapak) serta kawan-kawan anak merupakan faktor utama yang mempengaruhi akhlak anak. Sabda Rasululllah saw artinya: setiap anak yang dilahirkan ber- 
ada dalam keadaan fitrah, maka ibu bapaklah yang akan menjadikannya seorang yahudi dan nasrani atau majusi. (HR Muslim)

\section{Faktor Makanan}

Kebanyakan manusia kurang menyadari bahwa makanan ternyata juga punya kontribusi yang besar dalam membentuk prilaku manusia. Makanan yang halal akan membentuk pribadi yang baik dan makanan yang haram akan membentuk pribadi yang jelek. Makanan dalam agama diibarakan seperti tiang dalam bangunan, kalau kuat tiang tersebut maka kokohlah bangunan tetrsebut berdiri, jika tiang tersebut lemah, maka bergoyang-goyanglah bangunan itu lalu runtuh.

Menurut al-Gazali (1998:9) perut adalah sumber semua syahwat, yang daripadanya timbul bermacam-macam syahwat antara lain; syahwat sex. Jika syahwat sex sudah kuat akan menimbulkan nafsus senang harta, sebab kedua syahwat tersebut tidak akan tercapai kecuali dengan harta, dai nafsu harta akan timbul nafsu senang kedudukan karena mencari harta tanpa kedudukan adalah sukar. Ketika kedudukan telah dicapai maka akan bertumpuk-tumpuk penyakit dalam hati sperti takabur, riya, hasud, dendam dan sebagainya semuanya bersumber dari perut.

Lebih lanjut dalam hadist yang diriwayatkan oleh Abu Hurairah Ra. Rasulullah bersabda: " Perut adalah telaga bagi badan, dan urat-urat adalah saluran kepadanya, maka jika perut penuh (dengan makanan halal) maka urat-urat akan mengalirkan perkaraperkara baik (bagi tubuh) untuk menjadi taat, dan jika perut dipenuhi dengan makanan haram, urat-urat akan mengalirkan perkara buruk bagi badan dan akan berkelakuan buruk.

Faktor Pengetahuan ( Ilmu Agama)
Di samping genetik dan makanan , pengetahuan agama juga merupakan faktor yang mempengaruhi baik dan buruknya akhlak manusia. Ilmu merupakan asas untuk mengetahui yang baik dan yang buruk. Ilmu saja tidak cukup tetapi mestilah disertai dengan amal yang konsisten dan ikhlas

\section{PSIKOTERAPI HATI DALAM MENGATASI MASALAH AKHLAK DAN MORAL REMAJA}

Ketika hati manusia dikuasai nafs, maka saat itulah individu itu disebut dengan individu yang tidak memiliki hati atau hati yang mereka miliki telah mati Ketika hati sudah mati maka di sini individu terkadang berbuat semaunya tanpa peduli norma, aturan dan melahirkan masalah-masalah akhlak dan pelanggaran norma agama dan apapun bentuk nasehat dan teguran yang diberikan kepada individu tidak ada artinya sama sekali

Akan tetapi jika hati mampu melepaskan belenggu-belenggu nafs yang ada pada dirinya, maka secara otomatis individu itu akan berada di bawah pengaruh ruh, maka pada saat itulah manusia itu dengan seseorang yang telah memiliki hati; karena makna sebenarnya hati adalah bersih dari segala kekotoran nafs.

Menurut Muhammad Mahmud psikoterapi untuk mengatasi masalah agama dan akhlak remaja yang bersumber dari kerusakan hati manusia, dapat di atasi dengan psikoterapi hati. Dimana psikoterapi hati dapat dilakukan dengan 5 hal berikut:

\section{Terapi Alquran}

Alquran merupakan terapi yang pertama dan utama dalam Islam. Tingkat kemujarabannya tergantung kepada seberapa jauh tingkat sugesti keimanan 
pasien, yaitu dengan mendengar dan membaca, memahami dan menerangkan serta melaksanakan isi kandungannya. Masing-masing tahapan perlakuan terhadap alquran dapat menghantarkan klien ke alam yang dapat menenangkan dan menyejukkan jiwanya.

Firman Allah swt dalam surat al Isra' ayat 82, yang artinya: 'Dan kami turunkan al-Quran suatu yang menjadi penawar dan rahmat bagi orang-orang yang beriman dan al-Quran itu tidaklah menambah bagi orang yang zalim selain kerugian."

Adapun keistimewaan al-Quran menurut para ahli/ ulama antara lain adalah :

1. Menurut al-Qurtubi, terapi dengan alQuran dapat menghilangkan kebodohan dan keraguan, membuat jiwa yang tertutup serta dapat menyembuhkan jiwa yang sakit. Di samping itu juga dapat menyembuhkan penyakit fisik, baik dalam bentuk azimat ataupun tangkal.

2. Menurut Al-Tabathabai, mengemukakan bahwa alquran memiliki makna terapi ruhaniah yang dapat menyembuhkan penyakit batin. Dengan alQuran maka seseorang dapat mempertahankan keteguhan jiwa dari penyakit batin seperti keraguan dan kegoncangan jiwa.

3. Menurut Ibnu Qayyim al-Jauziyyah (1992:52-53), bacaan al-Quran dapat menyembuhkan penyakit jiwa dan badan manusia. Ibnu qayyim mengutip pendapat ibnu Taimiyyah yang menyatakan bahawa penyakit kronis/ masalah masalah pengamalan agama manusia seperti riya dan sombong. Penyakit riya dapat disembuhkan dengan dengan iyyakana'budu, sedangkan penyakit sombong dapat disembuhkan dengan iyyakanasta'in .

Pengobatan dengan al-Quran dapat dilakukan dengan metode ruqyah syariy- yah (jampi-jampi dengan al-Quran). Ruqyah syariyyah, merupakan jampijampi yang diperbolehkan oleh syariah, yang mendatangkan perlindungan, keridhoan dan kasih sayang Allah.

Ruqyah bermamfaat bagi orang yang terkenan gangguan syetan terhadap fisik atau jiwa, juga bagi tempat tinggal. Sedangkan bagi yang tidak terganggu dan memiliki keimanan yang kuat, maka ruqyah didengarkan sebagai penguat iman dan refresing rohani. Pada prinsipnya terapi dengan ruqyah bukanlah sekedar untuk mengatasi gangguan sihir itu saja, tetapi al-Qurana adalah obat sekaligus rohani bagi jiwa yang kering keimanannya dan pelita yang memancarkan nur ilahi dalam hati. Alllah akan memberikan pengaruh positif pada pasien melalui ruqyah.

Adapun metode yang dilakukan dalam memberikan ruqyah dapat digunakan melalui mendengarkan kaset-kaset ruqyah, selain itu juga dapat dilakukan dengan langsung mendengarkan ayatayat pelindung yang dibacakan oleh orang yang akan melakukan terapi baik di masjid maupun di rumah.

Secara umum ruqyah dilakukan dengan mengkuti tiga langkah berikut :

\section{Persiapan ruqyah}

Sebelum melakukan ruqyah baik untuk diri sendri maupun untuk orang lain bagi yang sudah positif terganggu maupun yang ingin mendeteksi ada gangguan atau tidak, hendaklah memperhatikan hal-hal berikut :

- Mempersiapkan suasana yang benar, keluarkan gambar-gambar yang ada di rumah yang akan dipakai untuk mengobati agar para malaikat berkenan memasukinya.

- Mengeluarkan dan membakar penangkal atau azimat pada penderita

- Membersihkan tempat dari pelanggaran syariat, seperti laki-laki yang 
memakai emas atau wanita yang tidak menutup aurat

- Jika meruqyah orang lain mesti memperhatikan

\section{Penanganan saat terjadi ruqyah}

Jika persiapan ruqyah telah selesai maka dilanjutkan untuk melakukan ruqyah baik untuk diri sendiri maupun orang lain. Dengan mendengarkan kaset ruqyah secara khusu' dapat memakai tip yang besar, dan dapat juga dilakukan dengan tiduran atau duduk, namun alangkah lebih baiknya ditemani. Jika ruqyah dilakukan untuk orang lain sebaiknya ia berbaring atau duduk dan mendengarkan kaset ruqyah dengan secara agak keras.

\section{Pasca Ruqyah}

Hal-hal yang mesti dijaga pasca ruqyah antara lain adalah :

1. Menjaga shalat lima waktu dengan berjamaah

2. tidak mendengarkan lagu dan tayangan maksiat

3. Sebelum tidur berwudu dan membaca ayat kursi, dua ayat terakhir alBaqarah, dan dekatkan keduan tangan ke mulut sambil membaca surat alIkhlas, al-falaq, an-Nas kemudian usapkan keseluruh badan yang terjangkau sebanyak $3 \mathrm{x}$

4. Tidak memasang gambar-gambar yang bernyawa di rumah

5. Membaca basmalah setiap memulai sesuatu

6. Setelah subuh dan maghrib membaca doa zikir pagi dan sore

7. membaca doa-doa yang di sunnahkan seperti doa masuk dan keluar rumah, wc. Masjid dan memasuki tempat baru.

\section{Terapi dengan shalat malam (qiya- mullail)}

Shalat malam yang dimaksudkan di sini bukan berarti shalat wajib dengan mengakhirkan shalat isya. Namun yang dimaksudkan adalah shalat sunnah se- perti shalat tahajud, hajat, mutlaq, tasbih, tarawih dan witir. Kemampuan terapi shalat sunnah ini sangat terkait dengan pengalaman shalat wajib sebab kedudukan terapi shalat sunnah hanya menjadi suplemen bagi terapi shalat wajib, sebagaimana firman Allah dalam surat alIsra' ayat 79 artinya: 'Dan pada sebagian malam hari bersembahyang tahajudlah kamu, sebagai suatu ibadah tambahan bagimu, mudah-mudahan tuhanmu mengangkat ke tempat yang lebih tinggi.

Dari ayat di atas nampak jelas bagi kita bahwa ayat tersebut menjelaskan tentang shalat tahajud. Tahajud berarti meninggalkan tidur, sedangkan yang dimaksud dengan shalat tahajud adalah shalat yang dikerjakan pada malam hari utamanya setelah bangun tidur.

Menurut Said Hawwa (1995:165) melakukan ibadah pada malam hari sangat berat hampir bagi semua orang, karena itu ia meperoleh pahala. Ibadah pada malam hari memiliki pengaruh dan kejernihan yang tidak ada pada saat-saat lain. Adapun masalah yang dapat diterapi dengan shalat malam adalah kotoran dan penyakit yang ada dalam diri manusia. Adapun kebersihan memiliki dua bahagian :

1. Kebersihan indrawi, yaitu kebersihan fisik manusia dari kotoran dan najis.

2. Kebersihan maknawi, yaitu kebersihan psikis manusia dari segala maksiat dan perbuatan tercela.

Kebersihan pertama berkaitan dengan syarat-syarat shalat, sedangkan kebersihan kedua berkaitan dengan kualitas dan kekhusukan dalam shalat. Kebersihan dalam shalat merupakan proses untuk mencapai kesehatan, sedangkan kesehatan merupakan hasil dari kebersihan, karena shalat itu merupakan terapi bagi penyakit manusia baik penyakit fisik mauspun psikis.

Dalam surat al-Maidah ayat 6 apabila dikaitkan dengan kesehatan memiliki dua dimensi yaitu : 
1. Dimensi indrawi yang dapat menyehatkan bagian-bagian dari organ tubuh manusia seperti wajah, kedua tangan, rambut dan kedua kaki bagian-bagian tersebut lazimnya tidak tertutup oleh pakaian manusia sehingga mudah sekali dihinggapi kotoran atau debu, dengan berwudhu' tangan dan kaki manusia menjadi bersih.

2. Dimensi maknawi yang dapat mensucikan jiwa manusia dari dosa-dosa yang diperbuat, kesucian jiwa merupakan fitrah asal manusia yang menggambarkan kesehatannya, jiwa dapat menjadi kotor dalam kehidupan sehari-hari. Seseorang melakukan anomani (ikhtiraf) seperti yang dilarang oleh Allah dan RasulNya. Menurut Ibnu Qayyim al-Jauziyyah jiwa yang kotor merupakan jiwa yang hidup, tetapi memiliki penyakit, jiwa seperti ini disebut nafs marid (jiwa yang sakit). Cara mengobatinya dengan melakukan amalan-amalan yang diperintahkan oleh Alah swt seperti dengan berwudhu'.

\section{Terapi dengan Puasa}

Menurut Najib Khalid Al Amir (1994: 193) banyak pemuda Islam yang terpaksa menunda niat menikah karena kondisi ekonomis. Tak dapat dipungkiri, keuangan sering menjadi kendala perkawinan bagi para pemuda dewasa ini. Sehingga tak jarang masalah ini justru membuat masalah baru dimana ada sebagian remaja yang akhirnya justru menyalurkan nafsunya dengan jalan yang tidak diridoi Allah swt. Sehingga hari ini banyak terjadi pergaulan bebas, perkosaan, dan sebagainya .

Rasulullah dalam hadist menyatakan "Wahai para pemuda, barang siapa di antara kamu telah memiliki kemampuan untuk menikah, maka bersegeralah menikah karena ia akan dapat menjaga pandangan dan memelihara ke- maluan. Barang siapa yang belum mampu, maka berpuasalah, karena puasa akan menjadi terapi/benteng" (Shahih Al Jami' As Shagir, Juz enem )".

Dari hadis di atas dapat kita lihat bahwa rasulullah menganjurkan kepada pemuda dan pemudi yang belum sanggup untuk menikah agar dapat berpuasa karena puasa itu akan menjadi benteng bagi kamu dari dosa. Dalam psikologi modern, hal ini disebut pemeliharaan, yaitu mengarahkan potensi dari suasana yang tidak diinginkan menuju suasana yang diingini, hal ini dapat membantu meringankan perasaan resah gelisah mereka.

Lebih lanjut menurut Najib khalid Al amir ( 1994: 195) anjuran berpuasa itu mempunyai beberapa hikmah :

1. Puasa menjauhkan pemuda dari lingkaran pikiran seksual dan hal-hal yang mengarah ke sana sehingga ia bisa menjaga dan memelihara mata dan kemaluannya dari terjerumus ke kehinaan. Orang yang puasa akan menghindarkan diri dari tontonantontonan media dan film forno yang tersebar di mana-mana.

2. Puasa menutup peluang bagi syetan untuk menggoda dan menyesatkan.

Berdasarkan uraian di atas menurut penulis bahwa puasa merupakan salah satu terapi yang penting yang mesti dimamfaatkan oleh remaja-remaja yang lagi puber pada hari ini untuk dapat menjauhkan diri mereka dari pergaulan bebas, menonton film forno dan membaca media pornografi dan prilakuprilaku menyimpang lainnya.

\section{Terapi dengan Zikir dan Doa}

Zikir adalah ucapan yang selalu mengingatkan kita kepada Allah swt. Dalam berzikir orang senantiasa mengingat dan menyebut asma Allah, sedangkan dalam berdoa orang mengajukan permohonan, minta bantuan, menyeru 
dan mengadu kepada Allah serta memuji-Nya.

Apabila ditinjau dari kesehatan mental, maka zikir dan doa berfungsi dalam pengobatan, pencegahan dan pembinaan akhlak dan moral muslim. Perawatan kejiwaan menghendak agar penderita mengingat kembali pengalaman lama, sehingga dengan demikian memudahkan penderita untuk mengadakan perubahan dan penyesuaian diri terhadap pengalaman baru.

Menurut Dadang Hawari doa dan zikir merupakan terapi psikoreligius yang dapat membengkitkan rasa percaya diri dan optimisme untuk melakukan penyembuhan penyakit. Percaya dir dan optimisme merupakan dua hal penting bagi penyembuhan penyakit, di samping obat serta tindakan medis. Dalam Islam umat yang sakit dianjurkan berobat kepada yang ahlinya disertai dengan berdoa,a dan berzikir .karena itu tidaklah lengkap apabila pengobatan medik tanpa diikuti dengan berdoa dan berzikir.

Dalam sebuah riwayat pernah diceritakan bahwa ada seorang pemuda yang datang ke majlis nabi dan minta izin kepada nabi untuk berbuat zina. Sahabat Umar bin Khattab lansung marah mendengarkan ungkapan tidak sopan pemuda tadi dan berdiri sambil mencabut pedang untuk memarahi pemuda tersebut. Namun Rasulullah menyuruh Umar kembali duduk dan mengajak pemuda tadi berdialog (konseling) yang bunyinya :

Rasul :Wahai anak muda bagai-mana jika ibumu yang dizinai orang ?

Pemuda :Saya tidak sudi ya rasullah

Rasul :Jika saudara perempuanmu?

Pemuda :Saya tidak sudi ya rasulullah

Rasul :Jika anak perempuanmu?

Pemuda :Saya tidak sudi ya rasullah

Rasul :Wahai anak muda jika demikian orang lain juga tidak sudi jika, ibunya, saudara perem- pauannya atau anak perempuannya engkau zinahi.

Pemuda :Kalau begitu tidak jadi ya Rasululullah.

Rasul :(Lalu Rasul meminta pemuda tadi mendekat dan memegang dada pemuda tadi dan mendoakan kepada Allah. Ya Allah lindungilah pemuda ini dari gangguan nafsu yang haram). Sejak itu pemuda tadi senantiasa berjalan menundukkan pandangan dan menjauhkan diri dari pergaulan bebas. (Najib halid Amir :1994 :118119)

Dari dialog di atas dapat diambil kesimpulan bahawa salah satu kiat yang dilakukan Rasul dalam mengatasi masalah pergaulan bebas remaja adalah dengan berdialog dan mendoakananya kepada Allah. Untuk itu menurut penulis bagaimana kita hari ini senantiasa senantiasa mendorong remaja yang mengalami masalah sulitnya menghindari pergaulan bebas tersebut didorong untuk banyak berdoa kepada Allah swt agar diberi kekuatan untuk menjauhkan diri dari segala bentuk kemaksiatan.

\section{Terapi dengan Muhasabah}

Muhasabah artinya adalah bagaimana seorang mukmin tersebut senantiasa mengintrospeksi dirinya ketika selesai melakukan amal perbuatan (Nasih Ulwan: 2006: 16). Apakah tujuan amalnya untuk memperoleh rido Allah atau apakah amalnya dirembesi sifat riya, apakah amalnya itu sudah baik atau amalnya buruk. Apakah prilakunya sebagai remaja sudah sesuai dengan ketentuan syariat atau justru prilakunya lebih banyak melanggar syariat Allah swt.

Oleh sebab itu remaja yang mengalami masalah berkaitan dengan penyimpangan moral dan akhlak serta ber- 
malas malasan dalam melaksanakan ajaran agamanya itu maka perlu kiranya diberikan terapi dengan muhasabah ini. Dengan muhasabah remaja diajak untuk merenungkan apa yang sudah mereka lakukan selama ini, sudah berapa umurnya, sudah berapa banyak dosa dan pelanggaran yang mereka lakuakan, sudah berapa banyak orang yang ia sakiti dan zalimi. Dengan metode ini biasanya banyak yang remaja yang selama ini hidup jauh dari tuntunan agama menjadi sadar dan taubat kepada Allah swt. Pelaksanaan metode muhasabah ini biasanya dilakukan dengan secara bersama-sama dalam satu kegiatan.

\section{PENUTUP}

Berdasarkan pembahasan di atas dapat disimpulkan bahwa di antara faktor yang menimbulkan timbulnya masalah dalam pengamalan agama dan rusaknya moral remaja hari ini antara lain karena rusaknya hati manusia.

\section{DAFTAR RUJUKAN}

Abdulah Nasih Ulwan. 2006. Tarbiyah Ruhiyah Petunjuk Praktis Mencapai Derjat Taqwa. Jakarta : Robbani Press

Abdul Mujib. 2001. Nuansa-nuasa Psikologi Islam. Jakarta: PT Raja Graindo.

Al-Gazali. 1998 Membersihkan Hati dari Akhlak yang Tercela: Jakarta: Pustaka Amani.

Atkinson. Rita L dkk. tt. Pengantar Psikologi. terj Widjaja Kusuma. Batam: Interaksara.

Chaplin,James. 1989 Kamus Lengkap Psikologi. Terj Kartini Kartono. Jakarta Rajawali.

Djawad Dahlan. 2005. Mengembangkan Fitrah Manusia dalam Upaya
Untuk itu upaya yang dapat dilakukan untuk mengatasi masalah agama dan moral remaja yang bersumber dari rusaknya hati manusia antara lain adalah dengan :

1. Mendorong remaja untuk senantiasa banyak membaca al-quran dan menjadikan al-Quran sebagai bacaan harian mereka.

2. Mendorong remaja untuk senantiasa menghidupkan sholat malam

3. Mendorong remaja untuk senantiasa memperbanyak puasa sunnat sehingga dirinya terpelihara dari godaan nafsu syetan yang menyesatkan

4. Mendorong remaja untuk senantiasa banyak berzikir dan berdoa kepada kepada Allah swt agar diberi kekuatan untuk menjauhkan diri dari perbuatan maksiat

5. Mendorong remaja untuk senantiasa melakukan muhasabah atau instropeksi diri atas semua kesalahan yang dilakukan.

Meraih Nur Ilahiah. Bandung: UPI.

Departemen Agama RI. Alquranul Qarim

Hawari Dadang. 2004. Alquran Ilmu Kedokteran dan Kesehatan Jiwa, Yogyakarta: Dana Bhakti Prima Yasa.

Hadtono, S.R. 1972 .Dasar-dasar Teori Bimbingan dan penyuluhan. Yogyakarta: PT Gunung Agung

Ibnu Qayyim al-Jauziyah. 1992. Madarij al-salikin bayn manazil iyyakana'budu waiyyakanasta'iin. Cairo Dar alfikri.

Mahmud, Muhammad. 1984. Ilm alNafs al Ma'ashir fi Dhaw'i al Islam. Jeddah: Dar al-Syuruq. 
Najib Khalid Al Amir. 1994. Tarbiyah Rasulullah. Jakarta: Gema Insani Press

Said Muhamamad Nuh. 2004. Terapi Mental aktifis Harakah.

Said, Hawwa. 1995. Jalan Ruhani Bimbingan Tasawwuf untuk Para aktivis Islam. Bandung: Mizan.
Prayitno. 1998. Konseling Pancawaskita. FIP IKIP Padang

Prayitno.1999. Dasar-dasar Bimbingan dan Konseling. Jakarta: Rineka Cipta

Prayitno. 1997. Pedoman AUM Umum, Jakarta: Dirjen Dikti Depdikbud

Winkel, WS.1987. Bimbingan dan Konseling di SMU. Jakarta : Gramedia 